\section{Å bedømme pasienters samtykkekompetanse}

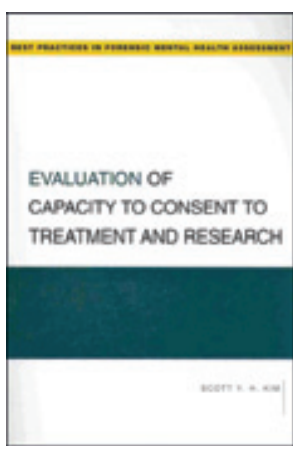

Scott Y.H. Kim

Evaluation of capacity to consent to treatment and research

203 s, tab, ill. New York: Oxford University

Press, 2010. Pris GBP 23

ISBN 978-0-19-532295-8

Denne boken tilhører serien Best Practices in Forensic Mental Health Assessment, som er beskrevet i en annen bokanmeldelse i dette nummeret av Tidsskriftet. Mens mange av de andre 19 bøkene er viet kriminologisk/psykiatriske emner, er denne boken av betydelig interesse for en videre målgruppe, der somatiske, medisinske problemstillinger spiller en stor rolle. Forfatteren er psykiater, har doktorgrad i filosofi og er amanuensis (assistant professor) ved University of Michigan. Hans intensjon er å gi en bred fremstilling av juridiske og medisinske problemstillinger og publikasjoner knyttet til samtykkekompetanse. Han bruker sin bakgrunn som liaison-psykiater, der praksis i USA er at de (trolig som her) blir brukt som hjelpere i særlig vanskelige avgjørelser i somatikken. I tillegg har han sin oversikt over de «rene» psykiatriske utfordringene og, ikke uviktig, sin filosofiske skolering og en betydelig interesse for det moderne faget nevroetikk.

Boken er systematisk og oversiktlig oppbygd med to hoveddeler. Til sammen er det åtte kapitler. Jeg liker både format, språk og layout. Første del er en fremstilling av både generelle og psykiatriske helsevernlover, i tillegg til en interessant empirisk fremstilling av en rekke unders $ø$ kelser over forekomsten av manglende samtykkekompetanse. Her rapporteres for øvrig fra Nord-Amerika og Storbritannia et overraskende høyt antall ikke-kompetente i forskjellige somatiske og psykiatriske materialer. Ett eksempel er at dette ble anslått hos $39 \%$ frivillig psykiatrisk innlagte(!). Annen del omhandler praktiske, kliniske og juridiske utfordringer, som forfatteren behandler særdeles grundig. Her gir han råd om undersøkelse, evaluering, konklusjon og iverksettelse. Klinikere og eventuelt jurister får prosedyreforslag og bl.a. også henvisninger til to USA-utviklede bedømmelsesinstrumenter for «competence» eller «capacity», som forfatteren for øvrig setter likhetstegn mellom.

Selv om det er likheter mellom bedømmelse av samtykkekompetanse for behandling og forskning, er det klare beskrivelser av forskjellene her. Dette settes inn i en interessant historisk sammenheng som går flere århundrer tilbake. Generelt understreker forfatteren at balansen mellom autonomi og velferd er vanskelig, og han viser til at selv meget erfarne og reflekterte klinikere ofte konkluderer forskjellig. Juridisk er det engelskspråklig tradisjon som legges til grunn, men når det gjelder samtykkekompetanse, synes jeg forskjellene til vårt land er relativt små. Jeg anbefaler boken for kolleger i somatikk og psykiatri, til medlemmer av både kliniske og forskningsetiske komiteer og til relevante juridiske instanser.

Pål Hartvig

Kompetansesenter for sikkerhets-, fengsels- og rettspsykiatri Oslo universitetssykehus

\section{Fortellinger om og for livet}

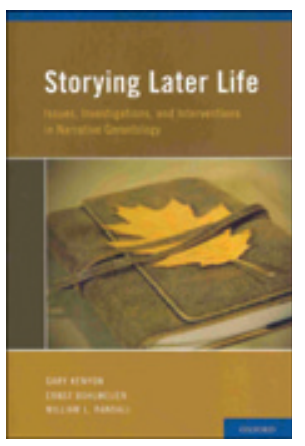

Gary Kenyon, Ernst Bohlmeijer,

William L. Randall, red.

Storying later life

Issues, investigations, and interventions

in narrative gerontology. $424 \mathrm{~s}$, tab, ill. Oxford:

Oxford University Press, 2011. Pris GBP 33

ISBN 978-0-19-539795-6

Boken er en innføring i narrativ gerontologi, en forholdsvis ung gren i læren om aldring og dens mangfoldige aspekter. I denne grenen utforsker forfatterne de biografiske dimensjonene av det å bli gammel, dvs. den indre opplevelsen og dens verbalisering - enten muntlig eller skriftlig - av egen livshistorie og nåværende situasjon.

Redaktørene har solide kunnskaper. Professor Gary Kenyon er en av grunnleggerne av narrativ gerontologi. Kapittelforfatterne er knyttet til akademiske miljøer i Canada, USA, Storbritannia og Nederland. Bidragene kommer overveiende fra områdene mental helse, atferdsfag og sosiologi, men også indremedisin, sykepleie, etikk og helseadministrasjon er representert.

Det er tre hoveddeler: viktige temaer, utforskninger og intervensjoner. Man kan lese kapitlene innen hver del uavhengig av hverandre. De har overkommelig omfang og rikelig med referanser. Det er få, men godt forståelige tabeller og illustrasjoner.

I temadelen belyser forfatterne hvordan mennesker som har levd en stund, kan oppfatte sitt liv: alt fra blindvei, villfarelse, misforståelse, skyld og soning, nedbrytning og forfall til nyorientering, ny mening og oppfyllelse. Slike oppfatninger er knyttet til samfunnsverdier, skiftende roller og sosiale rammer, følelsesmessige erfaringer og kroppens og sinnets helse. På ulike vis formidler forfatterne at et liv ikke består av en rekke enkelthendelser for oss, men at vi alltid legger en mening i disse og forsøker å knytte dem sammen til et større hele; en livsfortelling. Denne prosessen pågår hele tiden. Erindringen av fortiden er ikke fastspikret, men endres med nye erfaringer og meningen vi ilegger dem. Hos demensrammede mennesker vil denne fortellingen gradvis forsvinne, og det er det som skaper de største utfordringene for oss andre i kommunikasjonen med dem.

Utforskningsdelen inneholder blant annet studier om kroppsoppfatning, om kjønnsforskjeller i måten å presentere sin livshistorie på, og hvordan eldre kvinner opplever ny livsutfoldelse i en samfunnsengasjert gruppe (the raging grannies). Forfatterne presenterer metoder som reminisens- og skrivegrupper, gruppesamtaler for mennesker med krigstraumer og erindringsarbeid i parterapi hos eldre. Kapitlene er dels skrevet som vitenskapelige artikler, dels som kasuistikker.

Kapitlene i intervensjonsdelen er for meg de mest gripende fordi forfatterne her viser at det gjennom forskjellige erindringsog fortellermetoder er mulig å få gamle, kronisk syke mennesker og deres pårørende til å se konstruktive sammenhenger i fortiden, å oppdage at de har tilført samfunnet noe verdifullt, å forsone seg med forholdene slik de er, og finne en indre likevekt. Også alvorlig demente kan ha glede av det: Selv om deres egen fortelling er borte, kan de snakke om kjente gjenstander eller situasjoner og gi sin personlige vurdering av dem. Slik oppleves mening her og nå.

Jeg anbefaler boken for alle som arbeider med gamle syke. Den gir ettertanke, inspirasjon - og håp. Fortellingen fortjener mer rom, og det må det legges til rette for.

Renate Pettersen

Avdeling for rehabilitering og geriatri

Oslo universitetssykehus, Aker 